\title{
PERLINDUNGAN HUKUM BAGI PENDIDIK DALAM HUKUM PIDANA ISLAM
}

\author{
Didi Sumardi \\ UIN Sunan Gunung Djati Bandung \\ Email: didisumardi.fsh@gmail.com
}

\begin{abstract}
Abstrak
Tulisan ini membahas penerapan sanksi kepada peserta didik yang melanggar peraturan lembaga pendidikan dilihat dari aspek hukum pidana Islam. Di dalam hukum pidana Islam, penerapan sanksi kepada peserta didik yang melanggar tata tertib tidak termasuk jarîmah karena tidak melanggar hukum Allah SWT, namun hukuman yang diberikan kepada peserta didik, dikenai hukuman ta'zîr sebagai metode pendidikan yang bertujuan membuat jera pelanggar aturan. Hukuman ta'zîr tersebut bertujuan untuk mengembangkan potensi peserta didik agar menjadi manusia yang beriman dan bertakwa kepada Tuhan Yang Maha Esa, berakhlak mulia, serta menjadi orang yang bertanggung jawab sesuai dengan tujuan pendidikan Nasional. Bagi pendidik yang memberikan sanksi kepada peserta didik jika dilihat dari aspek hukum pidana Islam maka perlu mendapatkan perlindungan hukum, sehingga tidak muncul lagi orang tua peserta didik yang menuntut pendidik untuk dipenjarakan.
\end{abstract}

\section{Kata kunci : Hukum Pidana Islam, Pendidik, Perlindungan Hukum, Peserta Didik}

\section{Pendahuluan}

Penelitian ini dilatarbelakangi oleh adanya kasus yang menimpa pendidik, guru di Sekolah Dasar dan Dosen di Perguruan Tinggi. Beberapa bulan yang lalu seorang guru Sekolah Dasar di Majalengka harus berurusan dengan pihak kepolisian bahkan sampai ke Pengadilan untuk dipidanakan karena memotong rambut muridnya setelah beberapa kali murid diberikan peringatan untuk memotong rambutnya karena melanggar peraturan sekolah. Namun pihak orang tua murid tidak menerima tindakan guru tersebut dengan alasan mengganggu kebebasan dan kenyamanan peserta didik serta melanggar hak asasi manusia. Demikian juga kasus pembunuhan terhadap dosen oleh mahasiswa yang terjadi di salah satu Perguruan Tinggi di Sumatera karena sakit hati ditegur sedang mesum dengan pacarnya di tempat umum, padahal menurut informasi bahwa dosen yang menegur tersebut adalah dosen pembimbing akademik yang mempunyai tugas dan kewajiban membimbing serta mengarahkan mahasiswa bimbingannya.

Kasus tersebut menjadi bahan pemikiran bagi dunia pendidikan baik tingkat pendidikan dasar maupun pendidikan tinggi untuk melindungi para pendidik dari jeratan hukum sehingga pendidik tenang dalam menjalankan tugasnya, karena tugas pendidik 
selain menyampaikan ilmu pengetahuan terhadap peserta didik, juga memberikan bimbingan secara khusus agar peserta didik dapat berkembang mencapai kedewasaan. Usaha yang dilakukan untuk mencapai kedewasaan tersebut, setiap lembaga pendidikan memiliki peraturan untuk ditaati oleh seluruh stakeholder pendidikan, dan perlu disosialisasikan agar mereka memahami dan mengerti serta ikut bertanggung jawab dalam menegakan peraturan.

Pendidik sebagai makhluk ciptaan Tuhan yang mempunyai hak untuk membuat peraturan di lembaga pendidikan sejak lahir memiliki hak-hak dasar yaitu hak untuk hidup, hak untuk dilindungi, hak untuk bebas dan hak untuk mendapatkan perlindungan hukum, sehingga dalam melaksanakan tugasnya tidak diintervensi oleh pihak-pihak tertentu terutama dalam menegakan peraturan lembaga pendidikan.

\section{Pengertian Perlindungan Hukum}

Perlindungan berasal dari kata "lindung" yang memiliki arti perbuatan melindungi, penjagaan, atau memberikan perlindungan kepada orang-orang yang lemah. ${ }^{1}$ Secara umum perlindungan mengandung arti konservasi, pemeliharaan, dan penjagaan. Perlindungan dalam ilmu hukum adalah suatu bentuk pelayanan yang wajib dilaksanakan oleh aparat penegak hukum untuk memberikan rasa aman, baik fisik maupun mental, kepada korban. ${ }^{2}$ Perlindungan hukum adalah bentuk perlindungan yang diberikan terhadap subyek hukum dalam bentuk perangkat hukum yang bersifat preventif maupun represif, tertulis maupun tidak tertulis. Dengan kata lain, perlindungan hukum sebagai penjelmaan dari fungsi hukum, maksudnya hukum dapat memberikan suatu keadilan, ketertiban, kepastian, kemanfaatan dan kedamaian setiap individu.

Berdasarkan uraian di atas bahwa perlindungan hukum adalah bentuk pelayanan yang dilakukan oleh penegak hukum kepada seluruh masyarakat dan orang yang berperkara dari berbagai ancaman, teror, dan lain sejenisna, baik tertulis maupun tidak tertulis, sehingga setiap warga negara tetap merasa aman dari berbagai ancaman.

\section{Dasar Perlindungan Hukum}

Adapun yang menjadi dasar perlindungan hukum adalah sebagai berikut:

1. Al-Quran, sebagai sumber dari segala sumber hukum yang telah dirumuskan oleh Allah SWT untuk dijadikan sebagai pegangan dan acuan oleh manusia dalam merumuskan hukum berbangsa dan bernegara, dengan menjunjung tinggi nilai-nilai kemanusiaan;

2. Pancasila sebagai ideologi dan falsafah negara, menjadi acuan dalam merumuskan hukum demi kepentingan masyarakat;

\footnotetext{
${ }^{1}$ W.J.S. Poerwadarminta, Kamus Umum Bahasa Indonesia (Jakarta: Balai Pustaka. 2007), hlm. 707.

${ }^{2}$ Pasal 1 Peraturan Pemerintah Nomor 2 Tahun 2002 tentang Tata Cara Perlindungan Saksi dan Korban.
} 
3. Undang-Undang Dasar 1945 Pasal 1 Ayat (3) yang berbunyi: "Indonesia adalah negara hukum. Ini berarti bahwa Indonesia adalah negara yang berdasarkan atas hukum". Dengan sendirinya perlindungan hukum menjadi unsur esensial serta menjadi konsekuensi dalam negara hukum.

\section{Prinsip Perlindungan Hukum}

Prinsip perlindungan hukum bertumpu dan bersumber dari konsep tentang pengakuan dan perlindungan terhadap hak-hak asasi manusia yang diarahkan kepada pembatasan-pembatasan dan peletakan kewajiban masyarakat.

Prinsip perlindungan hukum di Indonesia adalah prinsip pengakuan dan perlindungan terhadap harkat dan martabat manusia yang bersumber pada Pancasila dan prinsip negara hukum. Prinsip perlindungan hukum, tidak bisa terlepas dari prinsip negara hukum, yaitu suatu pola untuk menghormati dan melindungi hak-hak kemanusiaan; suatu mekanisme kelembagaan negara yang demokratis; suatu sistem tertib hukum; dan adanya kekuasaan kehakiman yang bebas.

Prinsip perlindungan hukum diharapkan terpenuhinya kebutuhan yang diinginkan oleh rakyat dan negara, seperti adanya pengajuan terhadap jaminan hak-hak asasi manusia dan warga negara; adanya pembagian kekuasaan; pemerintah dalam melaksanakan kewajibannya harus selalu berdasarkan atas hukum yang berlaku, baik hukum yang tertulis maupun tidak tertulis; serta adanya kekuasaan kehakiman yang dalam menjalankan kekuasaannya terlepas dari pengaruh kekuasaan pemerintah.

Dengan demikian bahwa prinsip negara hukum menitik beratkan pada adanya hubungan hukum antara pemerintah dengan rakyat berdasarkan asas kerukunan; hubungan fungsional yang profesional antara kekuasaan-kekuasaan Negara; adanya prinsip penyelesaian sengketa secara musyawarah; serta terdapatnya keseimbangan antara hak dan kewajiban sesuai dengan fungsi masing-masing antara negara, rakyat, lembaga, serta penegak hukum, sehingga terwujudnya keseimbangan hak dan kewajiban masing-masing.

\section{Sarana Perlindungan Hukum}

Jika dilihat dari sarananya perlindungan hukum dibagi menjadi dua, yaitu sarana perlindungan hukum preventif dan sarana perlindungan hukum represif. Menurut Philipus, bahwa di Indonesia belum ada pengaturan secara khusus mengenai sarana perlindungan hukum preventif, yang ada adalah perlindungan hukum yang represif, seperti penanganan perlindungan hukum di lingkungan Peradilan Umum. Ini berarti bahwa perlindungan hukum baru diberikan ketika masalah atau sengketa sudah terjadi, sehingga perlindungan hukum yang diberikan oleh Peradilan Umum bertujuan untuk menyelesaikan sengketa.

Sarana perlindungan hukum yang bersifat preventif dapat dilihat dalam peraturan mengenai Hak atas Kekayaan Intelektual (HaKI), contohnya Undang-undang 
Nomor 14 Tahun 2001 tentang Paten. Perlindungan hukum ini berkaitan dengan hak dan kewajiban atas penemuan teknologi yang dipatenkan.

Perlindungan terhadap penemuan ini diberikan setelah penemu mengajukan permohonan paten untuk hasil temuannya. Sebagaimana tercantum dalam Undangundang Nomor 14 Tahun 2001 tentang Paten Pasal 20 yang membicarakan mengenai permohonan paten, setelah penemu memenuhi persyaratan yang diperlukan. Namun dalam realitanya temuan tersebut ada yang dipatenkan dan ada juga yang tidak dipatenkan. Walaupun paten tidak diberikan, setidaknya ini adalah bentuk perwujudan perlindungan hukum yang bersifat preventif, mencegah jika di kemudian hari ada sengketa mengenai temuan seorang penemu.

\section{Pengertian Pendidik}

Pendidik menurut bahasa (etimologi), artinya orang yang mendidik. Dalam bahasa Inggris dikenal dengan istilah teacher yang artinya guru atau pengajar, atau tutor yang berarti guru pribadi (private). Pendidik dalam bahasa Arab disebut ustadz atau ustadzah, mudarris, mu'allim, muaddib. Kata ustadz merupakan bentuk jamak dari asatidz yang berarti guru (teacher). Adapun kata mudarris berarti teacher (guru), instruktur (pelatih), trainer (pemandu), sedangkan kata muaddib berarti educator atau pendidik.

Secara terminologi, kata pendidik diartikan dengan guru, yaitu orang yang kerjanya mengajar atau memberikan pelajaran di sekolah atau di kelas. Menurut Abuddin Nata, pendidik adalah orang yang mendidik, yaitu orang yang melakukan kegiatan dalam bidang mendidik. Pendidik dalam perspektif pendidikan Islam adalah orang-orang yang bertanggung jawab terhadap perkembangan seluruh potensi peserta didik, baik potensi kognitif, afektif, maupun psikomotorik sesuai dengan nilai-nilai ajaran Islam.

Definisi pendidik dalam Undang-Undang Nomor 20 Tahun 2003 adalah tenaga kependidikan yang berkualifikasi sebagai guru, dosen, konselor, pamong belajar, widyaswara, tutor, instruktur, fasilitator, dan sebutan lain yang sesuai dengan kekhususannya, serta berpartisipasi dalam menyelenggarakan pendidikan. Kemudian dalam UndangUndang Guru dan Dosen Nomor 14 Tahun 2005 dijelaskan bahwa guru adalah pendidik profesional dengan tugas utama mendidik, mengajar, membimbing, mengarahkan, melatih, menilai, dan mengevaluasi peserta didik pada pendidikan anak usia dini jalur pendidikan formal, pendidikan dasar, dan pendidikan menengah.

Berdasarkan uraian di atas dapat diambil kesimpulan bahwa pendidik adalah orang yang bertanggung jawab membimbing perkembangan peserta didik sesuai dengan perkembangannya, baik perkembangan kognitif, afektif, maupun psikomotorik, sehingga mencapai kedewasaan.

\section{Syarat Pendidik}

Syarat-syarat umum bagi seorang pendidik adalah sehat Jasmani dan sehat Rohani. Namun demikian para ahli pendidikan masih memberikan kriteria persyaratan 
pendidik, seperti menurut Mubangit, bahwa syarat pendidik adalah: harus beragama; mampu bertanggung jawab atas kesejahteraan agama; serta harus memiliki perasaan panggilan hati nurani sebagai guru. Dengan demikian seorang pendidik harus memiliki sifat-sifat seperti memiliki integritas pribadi yang berkembang secara harmonis; memiliki integritas sosial, yaitu bisa menyatu dengan masyarakat; serta integritas susila, yaitu pribadi yang dapat menyatukan diri dengan norma-norma susila yang dipilihnya.

Menurut M. Athiyah al-Abrasyi bahwa seorang pendidik harus memiliki sifat-sifat tertentu agar ia dapat melaksanakan tugas-tugasnya dengan baik, seperti memiliki sifat zuhud, yaitu tidak mengutamakan materi dan mengajar karena mencari ridha Allah SWT harus jauh dari dosa besar; ikhlas dalam bekerja; pemaaf; dan mencintai peserta didiknya sebagaimana mencintai anaknya sendiri.

\section{Tugas dan Tanggung Jawab Pendidik}

Tugas dan tanggung jawab pendidik menurut ajaran Islam merupakan tugas yang sangat mulia, bahkan mendapat derajat yang tinggi. Sebagaimana Firman Allah SWT dalam OS. Al-Mujâdilah [58] ayat 11 yang artinya: "Hai orang-orang beriman apabila kamu dikatakan kepadamu: "Berlapang-lapanglah dalam majlis", Maka lapangkanlah niscaya Allah akan memberi kelapangan untukmu. dan apabila dikatakan: "Berdirilah kamu", Maka berdirilah, niscaya Allah akan meninggikan orang-orang yang beriman di antaramu dan orang-orang yang diberi ilmu pengetahuan beberapa derajat. dan Allah Maha mengetahui apa yang kamu kerjakan.

Tugas pendidik dalam dunia pendidikan adalah: pertama, membimbing potensi peserta didik sesuai dengan bakat serta minat yang dimilikinya; kedua, menciptakan situasi pendidikan; ketiga, pendidik harus memiliki pengetahuan yang diperlukan. Syaiful Bahri Djamarah menjelaskan tugas pendidik sebagai berikut: a) sebagai korektor, membedakan mana nilai yang baik dan mana nilai yang buruk; b) sebagai inspiratory, yaitu dapat memberikan inspirasi bagi kemajuan belajar peserta didik; c) sebagai informatory, yaitu dapat memberikan informasi perkembangan ilmu pengetahuan dan teknologi kepada peserta didik; d) sebagai organisator, yaitu mampu mengelola kegiatan belajar mengajar yang berkaitan dengan kemampuan manajemen sekolah; e) sebagai motivator, yaitu mampu mendorong peserta didik agar lebih semangat dan aktif dalam belajar; f) sebagai inisiator, yaitu bahwa pendidik harus menjadi pencetus ide-ide untuk kemajuan pendidikan; g) sebagai fasilitator, yaitu bahwa pendidik dapat memberikan fasilitas yang terbaik kepada peserta didik dalam proses pembelajaran; $h$ ) sebagai pembimbing, yaitu membimbing peserta didik agar menjadi manusia dewasa yang cakap; i) sebagai demonstrator, maksudnya bahwa seorang pendidik dituntut untuk mendemontrasikan materi pelajaran kepada peserta didik; j) menjadi pengelola kelas, supaya suasana di kelas terjadi interaksi edukatif yang menyenangkan; k) sebagai mediator, yaitu menjadi media yang berfungsi sebagai alat komunikasi guna mengefektifkan proses interaktif pembelajaran; I) sebagai supervisor, yaitu dapat memperbaiki, 
dan menilai proses pengajaran; dan m) sebagai evaluator, yaitu dituntut menjadi evaluator yag baik dan jujur demi kemajuan pendidikan.

Berdasarkan uraian tersebut, tugas pendidik dapat dikelompokan kepada tiga, yaitu tugas educational (pendidikan), maksudnya memberikan bimbingan yang lebih baik agar anak didik menjadi manusia yang sopan santun, menghargai orang lain, serta menyadari akan diri dan lingkungan sekitarnya; tugas intruksional, yaitu menitikberatkan pada pembinaan perkembangan dan kecerdasan daya intelektual peserta didik, dengan menekankan pada perkembangan kemampuan kognitif, afektif, dan psikomotor; dan tugas managerial (pengelolaan), yaitu mengelola lembaga pendidikan agar berkembang dengan baik.

Selain mempunyai tugas seperti yang telah dijelaskan di atas, pendidik juga memiliki tanggung jawab, yaitu: bertanggung jawab terhadap pembentukan moral peserta didik; kemajuan bidang pedidikan; kemasyarakatan; dan bertanggung jawab dalam bidang keilmuan. Dengan demikian bahwa tugas dan tanggung jawab pendidik adalah memberi bimbingan atau bantuan kepada peserta didik dalam perkembangan jasmani dan rohaninya demi mencapai kedewasaannya.

\section{Tujuan Pendidik}

Tujuan pendidik adalah menggantikan peran orang tua yang mempunyai tugas dan tanggung jawab dalam mendidik putra-putrinya, karena orang tua tidak mempunyai kemampuan terutama waktu, untuk mendidik putra-putrinya secara langsung dan terstruktur maka mereka menyerahkan tugasnya tersebut kepada pendidik.

Dengan demikian bahwa pendidik bertujuan sebagai pengganti peran orang tua di lembaga pendidikan yang mempunyai tugas khusus dalam membantu mengembangkan dan mengarahkan perkembangan potensi peserta didik agar dapat berkembang dengan baik dan dapat bermanfaat bagi kehidupan di masa yang akan datang.

\section{Pengertian Hukum Pidana Islam}

Hukum Pidana Islam merupakan terjemahan dari kata fikih jinayah. Fikih berasal dari bahasa arab (faqiha, yafqahu, fiqhan) yang berarti paham atau mengerti. Istilah jinayah, secara etimologi berasal dari kata janâ-yajnî-janyan-wa jinâyatan yang berarti berbuat dosa. ${ }^{3}$ Makna wa jinâyatan menurut Lowis Ma'luf berarti melakukan dosa, pelakunya disebut jân. ${ }^{4}$ Jinayah artinya perbuatan dosa, perbuatan salah atau jahat. Jinayah merupakan bentuk masdar dari kata kerja (fi'il madli) janâ yang mengandung arti suatu kerja yang diperuntukan bagi satuan laki-laki yang telah berbuat dosa atau salah. Pelaku kejahatan itu sendiri disebut dengan janî yang merupakan bentuk singular bagi satuan laki-laki atau bentuk mufrad mudzakkar sebagai pembuat kejahatan atau isim fấ'il.

\footnotetext{
${ }^{3}$ Ibrahim Anism dkk. al-Mu'jam al-Wasîth (Mesir: Majma' al-Lughah al-'Arâbiyyah. 1972), hlm. 141.

${ }^{4}$ Louis Ma'luf, al-Munjid fí al-Lughah wal-A'lam (Beirut: Dâr al-Masyâriq. t.th.), hlm. 105.
} 
Adapun sebutan pelaku kejahatan wanita adalah jâniyah, yang artinya dia (wanita) yang telah berbuat dosa.

Adapun pengertian jinayah menurut para fukaha adalah suatu istilah untuk perbuatan yang dilarang oleh syarak, baik perbuatan tersebut mengenai jiwa, harta, atau yang lainnya. ${ }^{5}$ Jinayah dalam definisi syarak adalah setiap perbuatan yang diharamkan, yaitu perbuatan yang dilarang oleh Allah SWT (syarak) karena mengandung bahaya bagi agama, jiwa, akal, kehormatan, dan harta. ${ }^{6}$ Jadi pengertian jinayah adalah semua perbuatan yang diharamkan, yaitu tindakan yang dilarang atau dicegah oleh syarak (hukum Islam), yang mempunyai konsekuensi membahayakan agama, jiwa, akal, kehormatan, dan harta benda.

Istilah lainnya dari jinayah adalah jarîmah. Jarîmah adalah perbuatan-perbuatan yang dilarang oleh syara yang diancam oleh Allah dengan hukuman had atau ta'zîr. Jarîmah, biasa dipakai sebagai perbuatan dosa, seperti pencurian, pembunuhan, perkosaan, atau perbuatan yang berkaitan dengan politik dan sebagainya. Oleh karena itu, digunakan istilah jarîmah pencurian, jarîmah pembunuhan, jarîmah perkosaan, dan jarîmah politik, dan bukan menggunakan istilah jinayah pencurian, jinayah pembunuhan, jinayah perkosaan, dan jinayah politik dan sebagainya.

Dengan demikian bahwa fikih jinayah adalah segala ketentuan hukum mengenai tindak pidana yang dilakukan oleh orang-orang mukallaf (orang yang dapat dibebani kewajiban), sebagai hasil dari pemahaman atas dalil-dalil hukum yang terperinci dari alQuran dan hadits. Pelakunya dikenai hukuman hadd atau ta'zîr.

\section{Tujuan Hukum Pidana Islam}

Tujuan hukum pada umumnya adalah menegakan keadilan berdasarkan kemauan pencipta manusia sehingga terwujud ketertiban dan ketentraman masyarakat. Oleh karena itu putusan hakim harus mengandung rasa keadilan agar dipatuhi oleh masyarakat.

Tujuan hukum pidana Islam adalah memelihara agama, jiwa, akal, harta dan keturunan. Oleh karena itu, kedudukan hukum pidana Islam amat penting dalam kehidupan bermasyarakat yang dapat dijadikan pedoman dalam kehidupan bermasyarakat, berbangsa, dan bernegara. Apabila hukum pidana Islam telah diaplikasikan dalam kehidupan, maka akan terwujud kehidupan yang aman, tentram, dan penuh keadilan.

\section{Sumber Hukum Pidana Islam}

Sumber hukum pidana Islam yang dijadikan petunjuk bagi kehidupan manusia terdiri atas al-Quran, as-Sunnah, dan al-Ra'yu. Pertama, al-Quran adalah sumber ajaran

\footnotetext{
5 Ibid.

${ }^{6}$ Sayyid Sabiq, Fiqh al-Sunnah (Beirut: Dâr al-Fikr. 2008), juz II, hlm. 716.
} 
Islam yang pertama, memuat kumpulan wahyu-wahyu Allah yang mengandung peraturan-peraturan hidup manusia dalam hubungannya dengan Allah, hubungannya dengan perkembangan dirinya, hubungannya dengan sesama manusia, dan hubungannya dengan alam beserta makhluk lainnya. Al-Quran memuat ajaran Islam, diantaranya: a) prinsip-prinsip keimanan sebagaimana dalam rukun iman; b) prinsip-prinsip syariah mengenai ibadah khas (shalat, puasa, zakat, dan haji) dan ibadah umum (perekonomian, pernikahan, pemerintahan dan sebagainya; c) janji dan ancaman; d) sejarah umat terdahulu; e) ilmu pengetahuan mengenai ilmu ketauhidan, agama, manusia, masyarakat, dan alam.?

Kedua, Sunnah Nabi Muhammad SAW yang menjelaskan ayat-ayat yang bersifat umum. Sunnah adalah perbuatan, perkataan, dan ketetapan Nabi Muhammad SAW (af'al, aqwal, dan taqrir). Ketiga, al-Ra'yu atau penalaran yaitu penggunaan akal pikiran manusia dalam menginterpretasi ayat-ayat al-Quran dan sunnah yang bersifat umum, yang biasa dilakukan oleh ahli hukum Islam. Oleh karena itu al-Ra'yu mengandung beberapa pengertian seperti: Ijma'; ljtihad; Qiyâs; Istihssan; Mashlahat Mursalah; Sad alDzari'ah; dan 'Urf.

Kesemuanya menjadi dasar dalam menentukan hukum pendekatan ra'yu, biasanya digunakan untuk menentukan hukum bagi persoalan yang muncul di masyarakat, yang belum ada ketentuan hukumnya secara nash. Melalui ra'yu tersebut hukum Islam menjadi fleksibel, bisa menjawab berbagai persoalan hidup sesuai dengan perkembangan zaman.

\section{Ruang Lingkup Hukum Pidana Islam}

Ruang lingkup hukum pidana Islam meliputi pencurian, perzinaan (termasuk homoseksual dan lesbian), menuduh orang baik-baik berbuat zina (al-Oadzaf), meminum minuman memabukan (khamar), membunuh atau melukai seseorang, pencurian, merusak harta seseorang, melakukan gerakan-gerakan kekacauan yang berkaitan dengan hukum kepidanaan. Hukum kepidanaan dimaksud disebut jarîmah.

Jarîmah terbagi dua, yaitu jarîmah hudûd dan jarîmah ta'zîr. Jarîmah hudûd adalah tindak kejahatan yang dilakukan oleh seseorang atau lebih yang menjadikan pelakunya dikenakan sanksi hadd.

Jenis-jenis hadd yaitu rajam, jilid atau dera, potong tangan, penjara atau kurungan seumur hidup, eksekusi bunuh, pengasingan atau deportasi, dan salib. Adapun jarîmah yang pelakunya diancam sanksi hadd, yaitu zina (pelecehan seksual); qadzaf (tuduhan zina); sariqah (pencurian); hirâbah (penodongan, perampokan, teroris); khamar (minuman dan obat-obat terlarang); bughâh (pemberontakan atau subversi); dan riddah atau murtad (pindah dari agama Islam). Selain jarîmah hudûd ada juga jarîmah ta'zîr,

\footnotetext{
${ }^{7}$ Zainuddin Ali, Hukum Pidana Islam (Jakarta: Sinar Grafika. 2007), cet. ke-1, hlm. 15.
} 
yaitu hukuman yang bersifat mendidik yang tidak mengharuskan pelakunya dikenai hadd dan tidak pula harus membayar kaffarah atau diyat.

Jenis hukuman jarîmah ta'zîr seperti hukuman penjara, skorsing atau pemecatan, ganti rugi, pukulan, teguran dengan kata-kata, dan jenis hukuman lain yang dipandang sesuai dengan pelanggaran dari pelakunya. Dalam hukum Islam jenis hukuman yang berkaitan dengan hukuman ta'zîr diserahkan sepenuhnya kepada kesepakatan manusia.

\section{Unsur-unsur Hukum Pidana Islam}

Sebelum menentukan suatu hukuman terhadap tindak pidana dalam hukum pidana Islam, diperlukan unsur syar'i (aturan), mâdi (perbuatan) dan unsur adabi (moral). Selain unsur tersebut, bahwa tindak pidana dalam hukum pidana Islam dapat dilihat dari beberapa segi yaitu:

a. Berat atau ringannya hukuman, dalam hukum pidana Islam dapat dibedakan menjadi: jarîmah hudûd; jarîmah qishash, dan jarîmah ta'zîr;

b. Segi unsur niat, ada dua jarîmah, yaitu disengaja, dan tidak disengaja;

c. Segi cara mengerjakannya, ada dua jarîmah, yaitu yang positif, dan negative;

d. Segi si korban, jarîmah itu ada dua, yaitu perorangan dan kelompok; dan

e. Segi tabiat, jarîmah terbagi dua, yaitu yang bersifat biasa dan bersifat politik.

Dengan demikian bahwa sebelum menentukan hukuman dalam hukum pidana Islam harus ditinjau dari berbagai aspek, sehingga hukuman yang dikenakan kepada pelaku benar-benar sesuai dengan ketentuan Islam yang dapat memberikan rasa keadilan bagi semua pihak.

\section{Asas-asas Hukum Pidana Islam}

Asas berarti alas atau landasan. Alas berarti bukti untuk menguatkan suatu keterangan. ${ }^{8}$ Bila kata asas dihubungkan dengan kata hukum sehingga menjadi asas hukum berarti kebenaran yang dipergunakan sebagai tumpuan berpikir dan alasan dalam mengemukakan suatu argumentasi, terutama dalam penegakan dan pelaksanaan hukum, yang berfungsi sebagai rujukan untuk mengembalikan segala masalah yang berkenaan dengan hukum. Asas-asas hukum Islam meliputi: asas-asas umum; asas-asas hukum pidana; asas-asas hukum perdata; asas-asas hukum internasional; asas-asas hukum administrasi negara, dan asas-asas lainnya.

Asas-asas umum hukum Islam adalah asas-asas hukum yang meliputi semua bidang dan lapangan hukum Islam seperti: asas keadilan; asas kepastian hukum; dan asas kemanfataan. Adapun asas-asas hukum pidana Islam adalah asas-asas hukum yang mendasari pelaksanaan hukum pidana Islam, seperti: asas legalitas; asas tidak berlaku surut; asas larangan memindahkan kesalahan kepada orang lain; dan asas praduga tak

${ }^{8}$ M. Daud Ali, Asas-asas Hukum Islam: Pengantar Ilmu Hukum dan Tata Hukum Islam di Indonesia (Jakarta: Rajawali Press. 1991), hlm. 112. 
44 | Asy-Syari'ah Vol. 20 No. 1, Agustus 2018

bersalah. Asas ini diambil dari ayat-ayat al-Quran yang menjadi sumber asas legalitas dan asas larangan memindahkan kesalahan pada orang lain.

\section{Kedudukan Hukum Pidana Islam}

Kedudukan Hukum pidana Islam merupakan salah satu peraturan Allah SWT yang terdapat dalam al-Quran dan Hadis. Dalam beberapa jenis hukum yang harus dilaksanakan tanpa reserve adalah hukum jinayah yang nashnya sudah pasti dan jelas, misalnya sanksi hukuman bagi pelaku pembunuhan, pelaku perzinaan, pencurian, perampokan, dan pemberontakan kepada Rasulullah SAW.

Dengan memperhatikan objek kajian dalam hukum pidana Islam, kedudukan hukum pidana Islam sangat mendukung eksistensi Islam di tengah kemajemukan masyarakat dalam pergaulan dunia Internasional. Terlebih, jika hukum pidana Islam mampu diterapkan dalam kehidupan masyarakat, khususnya di Negara yang penduduknya mayoritas muslim atau sekurang-kurangnya materi hukum ini menjadi bagian dari hukum pidana nasional Indonesia. ${ }^{9}$

Kedudukan inti hukum pidana Islam terletak pada penciptaan keadilan illâhiyyah dan insâniyyah; penciptaan kemanusiaan universal; penghapusan dosa-dosa duniawi; pelaksanaan keamanan sejati di dunia; perwujudan ketaatan kepada Allah dan RasulNya; pelaksanaan lembaga peradilan yang bermartabat dan berkeadilan; pelaksanaan asas persamaan hak dan kewajiban atas nama hukum; perwujudan tanggung jawab manusia dalam segala bentuk perbuatan; dan perwujudan tujuan hukum, yakni menjerakan pelaku kejahatan.

\section{Perlindungan Hukum bagi Pendidik dalam Hukum Pidana Islam}

Perlindungan hukum merupakan hak setiap individu sebagai warga negara yang dilindungi undang-undang, karena setiap warga negara mempunyai kedudukan yang sama dalam hukum. Pendidik yang berinteraksi langsung dengan peserta didik mempunyai tugas dan tanggung jawab mendidik, artinya disamping menyampaikan ilmu pengetahuan (transfer of knowlodge) juga mempunyai tugas membentuk sikap dan karakter peserta didik.

Dalam dunia pendidikan dibuat tata-tertib yang mesti diikuti oleh seluruh unsur pendidikan, termasuk peserta didik. Namun tidak sedikit tata-tertib sebagai aturan yang mengikat dalam dunia pendidikan tersebut dilanggar oleh peserta didik sehingga mengundang dijatuhkannnya sanksi bagi peserta didik yang melanggar. Tatkala sanksi dikenakan kepada yang melanggar, banyak yang menolak diberlakukannya sanksi tersebut, sehingga menimbulkan sengketa antara penegakan sanksi dengan yang dikenai sanksi yang berujung pada Pengadilan.

\footnotetext{
${ }^{9}$ lbid.
} 
Dalam Undang-Undang Nomor 14 Tahun 2005 tentang Guru dan Dosen dijelaskan, bahwa Guru adalah pendidik profesional dengan tugas utama mendidik, mengajar, membimbing, mengarahkan, melatih, menilai, dan mengevaluasi peserta didik pada pendidikan anak usia dini jalur pendidikan formal, pendidikan dasar, dan pendidikan menengah. Selanjutnya Pasal 2 ayat (1) dan (2) dijelaskan bahwa guru mempunyai kedudukan sebagai tenaga profesional pada jenjang pendidikan dasar, pendidikan menengah, dan pendidikan anak usia dini pada jalur pendidikan formal yang diangkat sesuai dengan peraturan perundang-undangan, yang dibuktikan dengan sertifikat pendidik.

Dengan demikian, guru wajib memiliki kualifikasi akademik, kompetensi, sertifikat pendidik, sehat jasmani dan rohani, serta memiliki kemampuan untuk mewujudkan tujuan pendidikan nasional. Kompetensi guru dimaksud dalam Pasal 8 meliputi kompetensi pedagogik, kompetensi kepribadian, kompetensi sosial, dan kompetensi profesional yang diperoleh melalui pendidikan profesi. Begitu beratnya tugas guru dalam meningkatkan mutu pendidikan nasional, sehingga perlu mendapatkan perlindungan hukum dalam menjalankan tugasnya.

Pasal 14 ayat (1) Undang-Undang tentang Guru dan Dosen menjelaskan bahwa dalam melaksanakan tugas keprofesionalan, guru berhak memperoleh perlindungan dalam melaksanakan tugas dan hak atas kekayaan intelektual; memiliki kebebasan dalam memberikan penilaian dan ikut menentukan kelulusan, penghargaan, dan atau sanksi kepada peserta didik sesuai dengan kaidah pendidikan, kode etik guru, dan peraturan perundang-undangan; dan memperoleh rasa aman dan jaminan keselamatan dalam melaksanakan tugas.

Berdasarkan Pasal 14 tersebut bahwa guru memiliki kebebasan dalam memberikan sanksi kepada peserta didik, termasuk memotong rambut peserta didik. Dengan demikian bahwa guru yang memberikan sanksi dengan cara memotong rambut peserta didik tidak termasuk pada tindak pidana, walaupun peserta didik sebagai anak dilindungi Undang-undang. Pendidik dikenai sanksi apabila melanggar sumpah dan janji jabatan; melanggar perjanjian kerja atau kesepakatan kerja bersama; atau melalaikan kewajiban dalam menjalankan tugas selama 1 (satu) bulan atau lebih secara terus-menerus. Pemberian sanksi dilakukan sesuai dengan peraturan perundang-undangan.

Pendidik (guru dan dosen) dalam Pasal 6 dijelaskan sebagai tenaga profesional bertujuan untuk melaksanakan sistem pendidikan nasional dan mewujudkan tujuan pendidikan nasional, yaitu membantu mengembangkan potensi peserta didik agar menjadi manusia yang beriman dan bertakwa kepada Tuhan Yang Maha Esa, berakhlak mulia, sehat, berilmu, cakap, kreatif, mandiri, serta menjadi warga negara yang demokratis dan bertanggung jawab.

Pendidik dalam melaksanakan tugasnya perlu mendapat perlindungan hukum supaya mempunyai kekuatan hukum, sebagaimana yang dijelaskan dalam Pasal 39 bahwa pemerintah, pemerintah daerah, masyarakat, organisasi profesi, dan atau satuan 
pendidikan wajib memberikan perlindungan terhadap guru atau pendidik dalam pelaksanaan tugas, yaitu perlindungan hukum, perlindungan profesi, serta perlindungan keselamatan dan kesehatan kerja. Juga perlindungan hukum dari tindak kekerasan, ancaman, perlakuan diskriminatif, intimidasi, atau perlakuan tidak adil dari pihak peserta didik, orang tua peserta didik, masyarakat, birokrasi, atau pihak lain.

Demikian juga dengan dosen sebagai pendidik profesional dan ilmuwan dengan tugas utama mentransformasikan, mengembangkan, dan menyebarluaskan ilmu pengetahuan, teknologi, dan seni melalui pendidikan, penelitian, dan pengabdian kepada masyarakat, sehingga dalam melaksanakan tugasnya berhak memperoleh perlindungan dan hak atas kekayaan intelektual; serta memiliki kebebasan dalam memberikan penilaian dan menentukan kelulusan peserta didik, sebagaimana dijelaskan dalam Pasal 51 Undang-Undang tentang Guru dan Dosen.

Dosen sebagai seorang pendidik dalam undang-undang tersebut dapat dikenai sanksi apabila melanggar sumpah dan janji jabatan; melanggar perjanjian kerja atau kesepakatan kerja bersama; atau melalaikan kewajiban dalam menjalankan tugas selama 1 (satu) bulan atau lebih secara terus-menerus. Pemberian sanksi tersebut dilakukan oleh penyelenggara pendidikan atau satuan pendidikan tinggi yang bersangkutan berdasarkan peraturan perundang-undangan.

Penerapan sanksi ta'zîr dalam hukum pidana Islam diserahkan kepada pemerintah. Guru dan Dosen sebagai pendidik yang ditetapkan berdasarkan surat keputusan pemerintah dan bagian dari pemerintah mempunyai hak untuk menerapkan ta'zîr di lembaga pendidikan. Sanksi ta'zîr yang dilakukan oleh pendidik terhadap peserta didik yang melanggar peraturan lembaga pendidikan, merupakan bagian dari Pembinaan pengembangan peserta didik yang mempunyai kekuatan hukum, dan tidak termasuk melanggar hukum, juga berbeda dengan sanksi ta'zîr yang diputuskan lembaga hukum, karena pelanggaran yang dilakukan oleh peserta didik juga bukan merupakan pelanggaran sebagaimana dalam jarîmah. Pelanggaran peserta didik adalah melawan terhadap aturan yang ditetapkan lembaga pendidikan (pendidik) yang semestinya ditaati dan dipatuhi sebagai cerminan dari akhlak mulia. Karena pendidik berfungsi sebagai orang tua di lembaga pendidikan, maka peserta didik semestinya memperlakukan pendidik sebagai orang tua kandung, harus taat dan patuh, bukan membangkang atau durhaka kepada pendidik sebagai orang tua, apalagi sampai ingin memenjarakan pendidik ke Pengadilan. Dengan demikian pendidik yang memberikan sanksi terhadap peserta didik bukan merupakan jarîmah dan tidak bisa dipidanakan.

\section{Penutup}

Pendidik (guru dan dosen) memberikan sanksi kepada peserta didik yang melanggar peraturan sekolah merupakan salah satu metode pembelajaran untuk mengarahkan perkembangan peserta didik dalam aspek kognitif, afektif, dan psikomotor. 
Sanksi yang diberikan pendidik kepada peserta didik merupakan wewenang pendidik yang dilindungi Undang-undang, yang bersifat mendidik. Berbeda dengan sanksi yang diberikan penegak hukum di Pengadilan, karena pendidik bukan penegak hukum. Namun demikian, pendidik berhak mendapat perlindungan hukum dari berbagai ancaman, teror, dan sejenisnya yang mengancam jiwa pendidik.

Dalam pendidikan Islam bahwa pendidik bertugas membimbing dan mengarahkan peserta didik agar menjadi orang yang beriman dan bertakwa kepada Allah SWT. Islam membolehkan memukul peserta didik yang tidak taat aturan, asalkan memukul ke anggota tubuh yang tidak membahayakan, dan sifatnya mendidik sekaligus memberikan sanksi agar peserta didik jera dan tidak melanggar lagi.

Dalam hukum pidana Islam, peserta didik yang memanjangkan rambut tidak termasuk jarîmah, namun melawan aturan yang dibuat lembaga pendidikan. Perbuatan melawan aturan perlu diberi sanksi ta'zîr sesuai dengan peraturan lembaga. Memotong rambut tersebut dalam hukum pidana Islam tidak digolongkan pada tindak pidana, tidak bisa diajukan ke Pengadilan untuk dipidanakan. Dengan demikian, pendidik yang terdiri atas guru dan dosen tidak perlu cemas dalam menerapkan peraturan terhadap anak didik di lembaga pendidikan, karena sesuai dengan undang-undang dan mendapat perlindungan hukum.

\section{Daftar Pustaka}

Al-Attas, Syed Muhammad Nuqaib. 1992. Konsep Pendidikan dalam Islam. Bandung: Mizan

Ali, Herry Noer. 1988. Azas-Azas Pendidikan Islam. Bandung: Diponegoro.

Ali, M. Daud. 1991. Asas-asas Hukum Islam: Pengantar Ilmu Hukum dan Tata Hukum Islam di Indonesia. Jakarta: Rajawali Press.

Ali, Mahrus. 2011. Dasar-dasar Hukum Pidana. Jakart: Sinar Grafika.

Ali, Zainuddin. 2007. Hukum Pidana Islam. Jakarta: Sinar Grafika.

Chazawi, Adami. 2002. Pelajaran Hukum Pidana. Jakarta: PT. RajaGrafindo Persada.

Departemen Agama RI. 2009. al-Quran dan Terjemahnya. Bandung: PT. Sygma Examedia Arkamlema.

H.R., Ridwan. 2010. Hukum Administrasi Negara. Jakarta: PT. RajaGrafindo Persada.

Hadjon, Philipu M. 1987. Perlindungan Hukum Bagi Rakyat di Indonesia. Surabaya: Bina Ilmu.

Hamzah, Andi. 1991. Asas-asas Hukum Pidana. Jakarta: Rineka Cipta.

2008. Asas-Asas Hukum Pidana. Jakarta: Rineka Cipta.

Hanafi, A. 1993. Asas-asas Hukum Pidana Islam. Jakarta: Bulan Bintang.

Kansil, C.S.T. dan Kansil, Christine S.T. 2007. Pokok-Pokok Hukum Pidana. Jakarta: PT. Pradnya Paramita.

Lamintang. 1997. Dasar-dasar Hukum Pidana Indonesia. Bandung: Citra Aditya Bakti. 
48 | Asy-Syari'ah Vol. 20 No. 1, Agustus 2018

Langgulung, Hasan. 1979. Falsafah Pendidikan Islam. Jakarta: Bulan Bintang. 1986. Manusia dan Pendidikan: Suatu Analisis Psikologi dan Pendidikan. Jakarta: Pustaka al-Husna.

Muljatno. 2008. Asas-asas Hukum Pidana. Jakarta: Rineka Cipta.

Muslich, Ahmad Wardi. 2006. Pengantar dan Asas Hukum Pidana Islam: Fikih Jinayah. Jakarta: Sinar Grafika.

Poerwadarminta, W.J.S. 1991. Kamus Umum Bahasa Indonesia. Jakarta: Balai Pustaka.

Ramayulis. 1990. Metodologi Pengajaran Agama Islam. Jakarta: Kalam Mulia.

Sabiq, Sayyid. 2008. Fiqh al-Sunnah. Beirut: Dâr al-Fikr.

Santoso, Topo. 2001. Menggagas Hukum Pidana Islam: Penerapan syariah Islam dalam konteks modernitas. Jakarta : Asyamil.

Sayyid, Fath al-Bab 'Abd al-Halim. 1996. al-Tarbiyyah fi al-Qur'ân wa al-Sunnah: alGhâyât wa al-Ahdâf. Kairo: Alam al-Kutub.

Tafsir, Ahmad. 1992. Ilmu Pendidikan dalam Perspektif Islam. Bandung: Remaja Rosdakarya.

Undang-Undang Nomor 20 Tahun 2003 tentang Sistem Pendidikan Nasional.

Undang-Undang Nomor 14 Tahun 2005 tentang Guru dan Dosen. 